\title{
Seasonal distribution of cadmium among components of sewage treatment ponds: an eco-tech for heavy metal remediation
}

\author{
S. Rana $\cdot$ S. K. Bag $\cdot$ B. B. Jana $\cdot$ J. K. Biswas
}

Received: 27 August 2011/Revised: 27 March 2012/Accepted: 6 July 2012/Published online: 17 April 2013

(C) Islamic Azad University (IAU) 2013

\begin{abstract}
The study was designed to quantify cadmium accumulation in different components of sewage treatment ponds during different seasons and to assess risk for human consumption perspective. The study estimated cadmium concentration in water, sludge, Eichhornia, plankton and tilapia fish from anaerobic, facultative, maturation- 1 and -4 ponds during pre-monsoon, monsoon and post-monsoon periods. It resulted that cadmium accumulated among different components of anaerobic, facultative, maturation-1 and -4 ponds ranging $0-18,0-10,0-7$ and $0-15.4 \mathrm{ppb}$, respectively. During monsoon, highest accumulation was observed in tilapia in both facultative and maturation ponds, but during post-monsoon, plankton community showed highest value in all. The highest bio-magnification of cadmium was recorded during monsoon with varying degrees (facultative pond: 4.39, maturation pond-1: 3.03 and maturation pond-4: 7.08). Cadmium concentration in tilapia lied within WHO's safe level and may be recommended for human consumption. The concentration of cadmium was estimated by Flame Atomic Absorption Spectrophotometer. The above findings occurred due to chelation, adsorption and sedimentation, absorption and bio-accumulation, ionization, leaching through sediment and rainfall. Water $\mathrm{pH}(6.7-8.8)$, dissolved oxygen $\left(0-17 \mathrm{mg} \mathrm{L}^{-1}\right)$, total solids (251-650 $\left.\mathrm{mg} \mathrm{L}^{-1}\right)$, iron $\left(\mathrm{Fe}^{2+}\right)$ concentration $\left(0.61-4.87 \mathrm{mg} \mathrm{L}^{-1}\right)$ and sedimentation rate $\left(278.9-2,409.6 \mathrm{~g} \mathrm{day}^{-1} \mathrm{~m}^{-3}\right)$ were conducive for the distribution of cadmium into different ecosystem components of treatment ponds. These ponds reclaimed 28.57-61.11\% of sewage-cadmium and may be promoted as a low-cost eco-tech for sewage treatment.
\end{abstract}

S. Rana · S. K. Bag · B. B. Jana · J. K. Biswas $(\bowtie)$ International Centre for Ecological Engineering and Department of Environmental Management, University of Kalyani, Kalyani, West Bengal 741235, India

e-mail: biswajoy2000@yahoo.com
Keywords Bio-accumulation - Cadmium reclamation . Ecosystem components - Ecological treatment ponds . Seasons $\cdot$ Sewage

\section{Introduction}

Bio-accumulation of the heavy metals, such as cadmium (Cd) in fish and other economically important organisms rearing in sewage-fed ponds has become a global enigma concerning its safety for human consumption. $\mathrm{Cd}$ is a highly toxic heavy metal posing a threat to human through food chain. The metal persists in aquatic, atmospheric and edaphic environment with a half life of 10-25 years (Landis and Yu 1999) and can affect aquaculture productivity. The metal tends to be accumulated within tissue of aquatic plants and animals for long even its very low concentration in water owing to non-covalent affinity to sulfhydryl group ( $-\mathrm{SH})$ of enzyme molecules. Besides, hydroxyl $(-\mathrm{OH})$, carboxyl $(-\mathrm{COOH})$, phosphatidyl, cysteinyl and histidyl side chain of protein, purine and porphyrin molecules also have moderate affinity to cadmium. In contrast, the divalent cadmium $\left(\mathrm{Cd}^{2+}\right)$ is a competitive inhibitor of metallo-enzymes, but in phytoplankton, it may substitute zinc in certain enzymes (Lane and Morel 2000). Creatine kinase in V-muscle is inhibited greatly at micromolar level of $\mathrm{Cd}$. Chronic exposure to $\mathrm{Cd}$ induces to increase the concentration of metallothionein protein within tissue like liver, gills and $\mathrm{V}$-muscle that binds $\mathrm{Cd}$ coordinately to reduce toxicity (Hollis et al. 2001). The induction of metallothionein synthesis is tissue specific and is displayed by different response patterns in gills, liver and kidney (Van Campenhpot et al. 2004). In liver, the activities of cytoplasmic glutamate-oxaloacetate transaminase (GOT), glutamate pyruvate transaminase (GPT), glutathione 
peroxidase and glutathione reductase are inhibited strongly by $\mathrm{Cd}$ due to competitive blockage of active site (Vaglio and Landriscina 1999). Liver mitochondrial MnSOD (Mn-super oxide dismutase) activity was observed to decline while substituting $\mathrm{Mn}^{2+}$ for $\mathrm{Cd}^{2+}$ (Casalino et al. 2002). The catalase activity in liver decelerates due to binding of $\mathrm{Cd}$ to imidazole group of His-74 which is essential in the decomposition of hydrogen peroxide (Casalino et al. 2002) and $\mathrm{Cu}-\mathrm{Zn}$ super oxide dismutase (Cu-Zn SOD) activity also decreased greatly (Novelli et al. 1998). At a concentration beyond $200 \mathrm{ppb}$, it is toxic to certain fishes, such as Oreochromis mossambicus, Oncorhynchus mykiss, Brycon cephalus, etc. (De 2000). Aquatic invertebrate and crustaceans are more sensitive to Cd toxicity compared to mollusks and polychaetes (Croteau Marie-Noele Luoma and Stewart 2005). Zooplanktons show more susceptibility to this heavy metal than phytoplankton but copepods exhibit high heavy metal tolerance (Kerrison et al. 1988). Hardness and salinity may confer environmental protection to some degree against ambient Cd toxicity (Lucas and Southgate 2003) because of the fact that $\mathrm{Ca}^{2+}, \mathrm{Mg}^{2+}$ and $\mathrm{Na}^{+}$ions may have competitive advantage for binding with the sulfhydryl groups of the enzyme molecule over the $\mathrm{Cd}^{2+}$ ion.

Cadmium enters in domestic sewage water from a broad array of sources like nickel-cadmium battery, photograph developing solution $\left(\mathrm{CdBr}\right.$ and $\left.\mathrm{CdI}_{2}\right)$, plastics, broken coloured glass, soap, printing ink, paper, rubber, textiles, fungicides, galvanized pipes, motor oil, etc. The compounds of the heavy metal remain dissolved in sewage water. The acidic nature of raw sewage ionizes the cadmium compounds, but the alkaline nature of sewage water in facultative and maturation pond in sewage water treatment plant influences cadmium ions to be bound with organic molecules. Most of the cadmium in raw sewage water is precipitated as insoluble sulfides or hydrated oxides in anaerobic ponds due to anaerobic condition (WHO 2006). Dissolved organic matter in the aquatic environment acts as organic ligand that plays an important role in counteracting the hazardous effects of heavy metals by the formation of chelating complexes (Jalali and Khanboluki 2007). This is particularly true for waste stabilization ponds with excessively high input of organic matters. It is well established that presence of organic compounds like humic and fulvic acids (Greter et al. 1979; Piotrowicz et al. 1983), nitrilotriacetic acid (Stoveland et al. 1979), and EDTA (Canterford and Canterford 1980) in water reduces the toxicity of heavy metals due to complex formation of the free heavy metal ions with these organic molecules (Kaplan et al. 1987). Buffle (1984) and Baccini (1984) reported that polysaccharides, peptides, organic acids, etc. secreted from bacteria of wastewater treatment ponds are potential chelators for heavy metals. A huge cellulose molecules (large polymer of $\beta$-D-glucose) in sludge and water could trap profuse $\mathrm{Cd}^{2+}$ covalently by hydroxyl group (Igwe and Abia 2006). Many algae, fungi and bacteria can act as important biosorbents (Fredickson et al. 2000). Hyper saturation of $\mathrm{O}_{2}$ aerates a strong oxidizing environment in surface water while anaerobic reducing environment at the bottom of sewage treatment ponds affect the solubility of heavy metal (Kaplan et al. 1987). Continuous flow of sewage water in waste stabilizing pond reduces sedimentation rate of stable compound and suspends them in water. On the other hand, microbial decomposition of the compounds makes the metal free and soluble in water. Biswas and Santra (2000) reported that fishes (L. rohita, C. mrigala and O. mossumbicus) grown in municipal wastewater-fed bheris in Kolkata Metropolitan area, accumulated Cadmium from 0.05 to $0.12,0.39$ to 0.8 and 0.9 to $1.2 \mu \mathrm{g} \mathrm{kg}^{-1}$, respectively, on the dry weight basis. Haq and Ghosal (2000) observed that cadmium was accumulated to the tune of 2.5-5.0 and $0-2 \mathrm{mg} \mathrm{kg}^{-1}$, respectively in sediments and duckweeds in duckweed based wastewater treatment system in Bangladesh. In wetland ponds of West Bengal, India, the study of Das and Jana (2004) showed that cadmium was accumulated in sludge, root and leaf tissue of Eichhornia, liver and gills of Lamellidens marginalis to the ranges of $7-77 \mu \mathrm{g} \mathrm{g}^{-1}$, 40-152, 9-63, 17-502 and 15-258 $\mathrm{g}^{-1}$, respectively, on dry weight basis. Treatment wetlands have evolved into a reliable wastewater treatment technology for wastewater reclamation and remediation (Vymazal 2007 and Vymazal 2010; Lazareva and Pichler 2010; Maine et al. 2007). Several hydrophytes in treatment wetlands have been proved effective in accumulation, removal, detoxification and/or immobilization of heavy metals (Singh et al. 2012; Liu et al. 2007). Kaoud et al. (2011) experimentally proved that Lemna gibba L-extract had the capability in chelating cadmium ion $\left(\mathrm{Cd}^{2+}\right)$ from the media and thus the weed and its extract could be an effective tool in removing cadmium from water and in reducing cadmium accumulation in fish. The present study was undertaken to estimate the concentration of cadmium in different ecosystem components of the sewage treatment ponds, like water, sludge, Eichhornia, plankton and fish (tilapia), and to evaluate the quality of the fish reared in sewage water from human consumption point of view. The study was carried out in sewage treatment ponds in Kalyani Municipality, West Bengal, India, from May 2007 to September 2007.

\section{Materials and methods}

\section{Experimental ponds}

The sewage treatment ponds employed in the present study fall under three different categories: two anaerobic $(26 \mathrm{~m} \times$ $52 \mathrm{~m} \times 2.5 \mathrm{~m})$, two facultative $(64 \mathrm{~m} \times 150 \mathrm{~m} \times 1.5 \mathrm{~m})$ and four maturation ponds $(52 \mathrm{~m} \times 156 \mathrm{~m} \times 1 \mathrm{~m})$. All 
ponds were arranged in succession as shown in Fig. 1. Anaerobic ponds were vertically connected to facultative ponds. Both facultative pond- 1 and Facultative Pond- 2 were connected to maturation pond-1. Four maturation ponds were in a series and are interconnected in a zig zag way. Maturation Pond-4 was connected to a canal falling into the river Ganga (Fig. 1). The domestic raw sewage influx was made into the anaerobic pond through an inlet and was disposed out finally to that canal via an outlet from the last maturation pond.

\section{Collection of water}

Surface water was collected from five sites with two sub sites of one meter distance-inlet of anaerobic pond $\left(\mathrm{AP}_{\mathrm{in}}\right)$, outlet of anaerobic pond $\left(\mathrm{AP}_{\text {out }}\right)$, outlet of facultative pond $\left(\mathrm{FP}_{\text {out }}\right)$, outlet of first maturation pond (MP- $1_{\text {out }}$ ) and outlet of fourth maturation pond (MP-4 ${ }_{\text {out }}$ ) (Fig. 1), three times at a time in the months of May, July and September, 2007 maintaining respective retention time of these ponds. A portion of each sample was kept for analysis of water quality and the rest for the estimation of cadmium content with the treatment of $\mathrm{HNO}_{3}(69 \%)$ at $1 \mathrm{ml}$ per $100 \mathrm{ml}$ sample.

\section{Collection of sludge}

Sludge samples were collected by keeping an plastic beaker of $500 \mathrm{ml}$ (Turson, Germany) on the bottom of the pond at the above stated sites, sub sites and times of May,

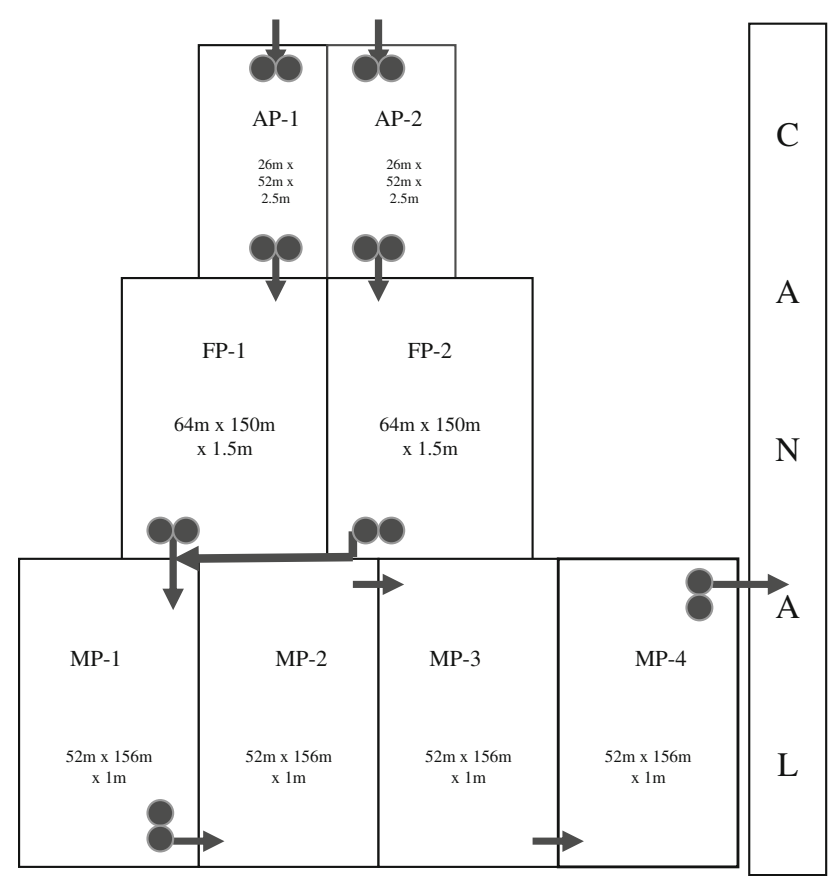

Fig. 1 Schematic diagram of Kalyani sewage treatment ponds series, where $A P$ anaerobic pond, $F P$ facultative pond, $M P$ maturation pond, arrow direction of water flow through inlet and outlet and filled circle sampling sites
July and September of the year 2007 (Fig. 1). These sludge samples were then dried at $60-70{ }^{\circ} \mathrm{C}$ at hot air oven till a constant weight was obtained. Dried sludge was then pounded to fine powder by mortar and pestle.

Collection of plankton, water hyacinth and tilapia

Samples of net plankton, water hyacinth and tilapia were collected from the test ponds at regular intervals. Planktons were captured from water by plankton net (mesh size $75 \mu \mathrm{m})$. From each pond, three specimens each of well grown water hyacinth and fish (weight 50-100 g) were procured. Fishes were dissected and their gill, liver and muscle tissues were collected carefully for subsequent processing. All the materials (water hyacinth, plankton and fish tissues) were dried separately at $60-70{ }^{\circ} \mathrm{C}$ till a constant weight was obtained. The samples were pooled to create a homogenous one.

Sample processing and estimation

Water, sludge, plankton, water hyacinth and fish tissue were prepared for the estimation of Cadmium following the protocol of APHA (1995) and its quantification was done by the Flame Atomic Absorption Spectrophotometer (AAS) (Company: Varian, Australia and Model: AA 240).

Water quality

The water quality parameters namely $\mathrm{pH}$, total alkalinity, dissolved oxygen (DO), orthophosphate-P, turbidity, total solids (TS), total dissolved solids (TDS), total suspended solids (TSS) and chemical oxygen demand (COD) of anaerobic, facultative and maturation ponds were estimated following methods of APHA (1995).

Rate of distribution

The rate of distribution is the partitioning of a substance in fluid per unit time from its source into different compartments of the system. The rate of distribution of cadmium from abiotic component (water and sludge) to biotic components (Eichhornia, plankton, tilapia and others) was estimated by the following formula

Rate of distribution (ppb day $\left.{ }^{-1}\right) \frac{\left(W_{\mathrm{cd}}+S_{\mathrm{cd}}\right)_{i}-\left(W_{\mathrm{cd}}+S_{\mathrm{cd}}\right)_{f}}{t}$

$W_{\text {cd }}$ is the concentration of cadmium in water, $S_{\text {cd }}$ is the concentration of cadmium in sludge, $i$ is the initial, $f$ is the final, and $t$ is the retention time

Rate of sedimentation

Rate of sedimentation means settling of heavy substances in fluid per unit time per unit volume. 
Sedimentation rate of solid matter in sewage water was estimated by the following formula

Rate $\left(\mathrm{g} \mathrm{day}^{-1} \mathrm{~m}^{-3}\right)=\frac{w}{t \times v}$

$W$ is the weight of sludge, $t$ is the incubation time and $v$ is the volume of water, where $\mathrm{v}=2 \pi \mathrm{r}^{2} \mathrm{~h} ; r$ is the radius of the container, $h$ is the depth of water body.

In the present sewage treatment ponds, $r=0.04 \mathrm{~m}$ and $h=2.5 \mathrm{~m}$ for anaerobic pond, $1.5 \mathrm{~m}$ for facultative pond and $1 \mathrm{~m}$ for maturation pond.

\section{Bio-concentration factor $(\mathrm{BCF})$}

Bio-concentration is the build-up of pollutant in an aquatic organism by direct uptake from the ambient water. Bioconcentration factor of cadmium within the body of tilapia, Eichhornia or plankton that depended on both water and sediment media was estimated by the following formula

$\mathrm{BCF}$ (in times) $=\frac{B_{\mathrm{cd}}}{\frac{1}{2}\left(W_{\mathrm{cd}}+S_{\mathrm{cd}}\right)}$

$B_{\text {cd }}$ is the concentration of cadmium within body, $W_{\mathrm{cd}}$ is the concentration of cadmium in water, $S_{\mathrm{cd}}$ is the concentration of cadmium in sludge, respectively.

Tissue concentration factor (TCF)

Tissue concentration indicates concentration of a non-biodegradable toxicant within a tissue of an organism.

Similarly, TCF (in times) $=\frac{T_{\mathrm{cd}}}{\frac{1}{2}\left(W_{\mathrm{cd}}+S_{\mathrm{cd}}\right)}$

$T_{\text {cd }}$ is the concentration of cadmium in the specific tissue, $W_{\mathrm{cd}}$ is the concentration of cadmium in water, $S_{\mathrm{cd}}$ concentration of cadmium in sludge.

\section{Bio-magnification factor (BMF)}

Bio-magnification is an increase in concentration of recalcitrant pollutant in the bodies of living organisms at successively higher trophic levels in the food chain. As Tilapia consumes both root of Eichhornia and planktons, so the quantification of bio-magnification factor (BMF) in case of tilapia entails both the concentrations encountered in Eichhornia and planktons and it amounts to the ratio between the metal load in the body of tilapia and the average concentration of the two edibles.

$\mathrm{BMF}$ (in times) $=\frac{B_{\mathrm{cd}}}{\frac{1}{2}\left(R_{\mathrm{cd}}+P_{\mathrm{cd}}\right)}$

$B_{\mathrm{cd}}$ is the concentration of cadmium within body, $R_{\mathrm{cd}}$ is the concentration of cadmium in root of Eichhornia, $P_{\mathrm{cd}}$ is the concentration of cadmium in plankton.

\section{Statistical analyses}

The data presented as the arithmetic mean of six samples $(n=6)$. The sampling coupled with preparation error was estimated as standard error of mean $( \pm \mathrm{SE})$. Data tabulated with mean $\pm \mathrm{SE}$. The variance of mean among the concentrations of cadmium at different sites was tested by oneway ANOVA at $5 \%$ level of significance (Software Pakage: SPSS 10.00) and the comparison between any two sites or any two components were tested by multiple comparison test Tukey's at $5 \%$ level of significance (Software Pakage: SPSS 10.00). Statistical significance was accepted as $P<0.05$.

\section{Results and discussion}

Seasonal distribution of cadmium (Cd) in anaerobic pond (AP), facultative pond (FP), maturation pond-1 (MP-1) and maturation pond-4 (MP-4).

\section{Distribution}

The concentration of cadmium in water, sludge, plankton, Eichhornia and Tilapia in anaerobic, facultative, maturation-1 and maturation -4 ponds during pre-monsoon, monsoon and post monsoon periods have been tabulated in Table 1 and their proportionate distribution in ponds and seasons have been shown in Fig. 2. In water, the average concentration of cadmium and its proportionate distribution were highest in all ponds during post-monsoon and were lowest in all ponds during monsoon (Table 1; Fig. 2). The average highest cadmium concentrations in water were $1.4-2.9 \times$ in the values of their respective ponds during premonsoon (Table 1). In case of sludge component, the highest concentrations and proportionate distributions of cadmium were observed in pre-monsoon and the lowest in monsoon in all ponds (Table 1 and Fig. 2). The average cadmium concentrations in sludge in all ponds during premonsoon were greater 1.2-3.4 times that of the respective ponds in monsoon and post-monsoon. In both water and sludge, anaerobic pond carried the highest cadmium concentration and proportionate distribution irrespective of seasons (Table 1; Fig. 2). Metal concentration in facultative pond plankton that showed the highest in pre-monsoon among all the ponds and seasons were remarkably greater (4.7-5.7 $\mathrm{x}$ ) than facultative, maturation-1 and -4 ponds in monsoon (Table 1), but it was not greater significantly (0.14-0.16×; one-way ANOVA, Tukey's test, $P>0.05$ ) than the ponds in post-monsoon (Table 1). In both pre- and post-monsoon, Eichhornia (leaf and root) of anaerobic pond accumulated highest metal content among the ponds (Table 1 and Fig. 2). In general, the degree of accumulation in root outweighed its distribution in leaf (Table 1). The distribution in V-muscle in tilapia was less in all ponds and seasons, but the reverse was the case for liver (Table 1). The distribution peak was recorded in fish liver from maturation pond-4 followed by gill from maturation pond-4 during monsoon (Table 1). 


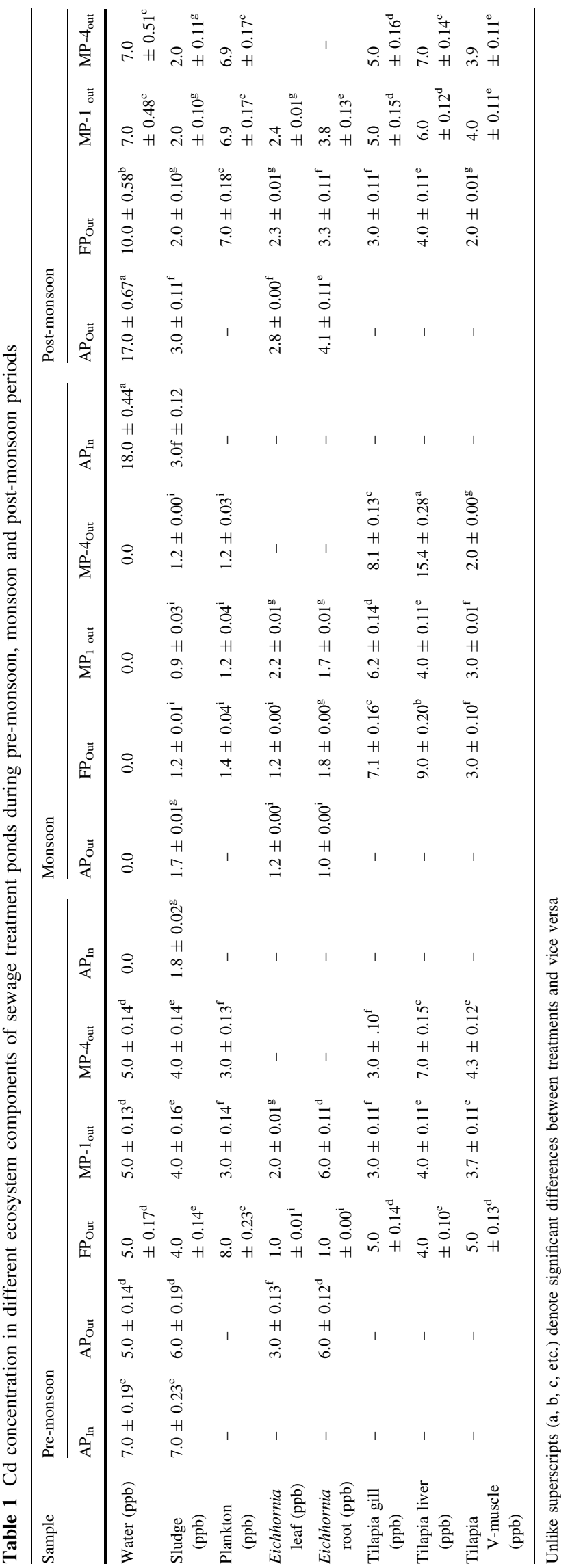

Rate of distribution

The rate of Cd distribution into different biotic components of treatment ponds reached the highest level in pre-monsoon anaerobic pond followed by post-monsoon facultative pond whereas, the rate was significantly slackened (3-28.9×; one-way ANOVA; Tukey's test, $P<0.05$ ) during monsoon (Table 2).

Rate of sedimentation

The highest rate of sedimentation was observed in anaerobic ponds during all the seasons. The trend of variation followed the order: AP $>$ MP-4 $>$ MP-1 $>$ FP in all three seasons (Table 3).

\section{Bio-concentration}

For Eichhornia, the highest degree of cadmium accumulation occurred in maturation pond-1 during all seasons. The concentration in anaerobic pond, facultative pond and maturation pond-1 during monsoon were significantly higher (2.7-10.4×; one-way ANOVA; Tukey's test, $P<0.05)$ than their respective ponds during pre- and post monsoon (Table 2).

Plankton community in facultative, maturation-1 and maturation- 4 ponds, accumulated the highest concentration of Cd during monsoon period (Table 2). The accumulation in maturation- 1 and maturation-4 ponds planktons did not vary significantly (one-way ANOVA; $P>0.05$ ) during pre-monsoon, monsoon and post-monsoon period (Table 2). In case of tilapia, during monsoon the facultative, maturation- 1 and -4 ponds showed the highest metal accumulation (one way ANOVA; Tukey test, $P<0.05$; Table 2) which were 8.8- to 21.2-fold of the respective ponds during pre- and post-monsoon periods.

\section{Bio-concentration}

For Eichhornia, the highest degree of cadmium accumulation occurred in maturation pond-1 during all seasons. The concentration in anaerobic pond, facultative pond and maturation pond-1 during monsoon were significantly higher (2.7-10.4×; one-way ANOVA; Tukey's test, $P<0.05)$ than their respective ponds during pre- and postmonsoon (Table 2).

Plankton community in facultative, maturation-1 and maturation- 4 ponds, accumulated the highest concentration of $\mathrm{Cd}$ during monsoon period (Table 2). The accumulation in maturation-1 and maturation-4 ponds planktons did not vary significantly (one way ANOVA; $P>0.05$ ) during pre-monsoon, monsoon and post-monsoon period (Table 2). In case of tilapia, during monsoon the facultative, maturation- 1 and -4 ponds showed the highest metal 

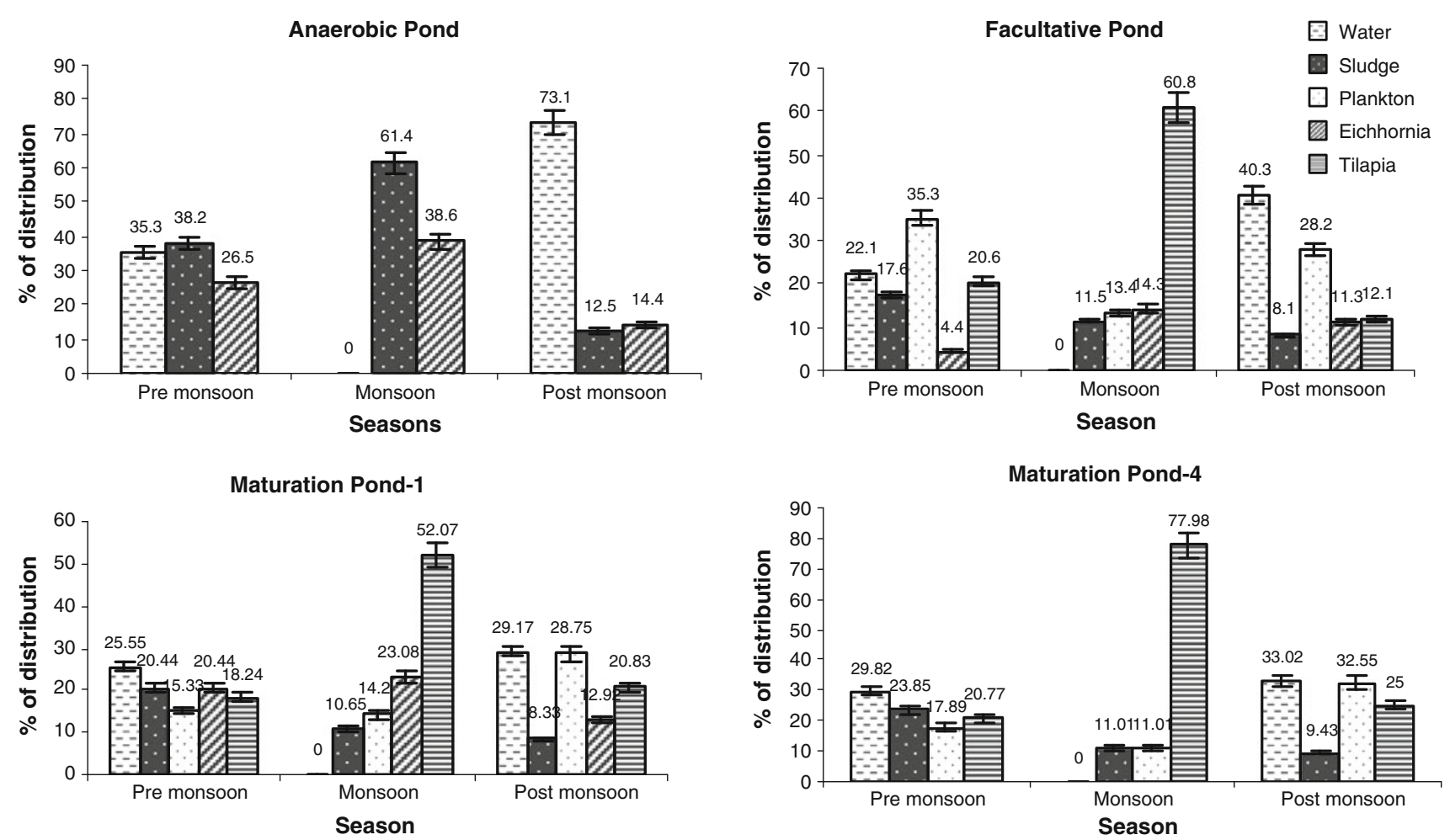

Fig. 2 Distribution (\%) of cadmium in different ecosystem components of treatment ponds during pre-monsoon, monsoon and post-monsoon periods. Bar $(\mathrm{T})$ represents standard error of mean

accumulation (one-way ANOVA; Tukey's test, $P<0.05$; Table 2) which were 8.8- to 21.2-fold of the respective ponds during pre- and post-monsoon periods.

\section{Tissue concentration}

Tissue concentration factors in Eichhornia leaf in anaerobic, facultative and maturation-1 ponds reached the peak during monsoon (Table 2) while monsoon maturation pond-1 showing the highest value (Table 2). In case of Eichhornia root, the factor in maturation pond-1, carried peak values during pre-monsoon, monsoon and post-monsoon periods (Table 2). Monsoon tissue concentration factors were always higher (one-way ANOVA; Tukey's test, $P<0.05$ ) relative to the pre-and post-monsoon factors (Table 2). The concentration factor in tilapia gills, liver and $\mathrm{V}$-muscle were shown higher values in monsoon than preand post-monsoon periods (Table 2). Maturation pond-4 recorded peak values in gills and liver during monsoon among all seasons (Table 2). In monsoon, the factor in liver tissue in maturation ponds -4 was 0.9 and 6.7 magnitude higher than gills and $\mathrm{V}$-muscle, respectively.

\section{Bio-magnification (BM)}

Bio-magnification of cadmium was studied in tilapia only because, tilapia was the top consumer in these treatment pond ecosystems. Bio-magnification was expressed markedly in facultative, maturation- 1 and -4 ponds during monsoon than pre- and post-monsoon periods (Table 2). Maturation pond-4 was shown peak values during premonsoon and monsoon (Table 2). Bio-magnification factor in monsoon maturation pond- 4 was 3.5 times higher than pre-monsoon maturation pond-4 (Table 2).

\section{Comparative seasonal distribution of $\mathrm{Cd}$ in sewage treatment ponds}

\section{Pre-monsoon}

The anaerobic pond exhibited the highest cadmium concentration in water $(35.3 \%)$ and sludge (38.2\%) among all ponds (Fig. 2). Plankton community accumulated the metal in highest quantity $(35.3 \%)$ in facultative pond. Least accumulation was recorded in Eichhornia (4.4\%) in facultative pond. No appreciable change in cadmium accumulation in tilapia (18.24-20.77\%) occurred among the ponds (Fig. 2). In maturation pond-1 and -4 , the accumulation in abiotic components (water plus sludge) and in biotic components (plankton plus Eichhornia plus tilapia) were almost equal (1:1) but in facultative pond the accumulation in biotic components was $51.89 \%$ higher than that in abiotic components. Eichhornia root showed the highest tissue concentration factor in maturation 


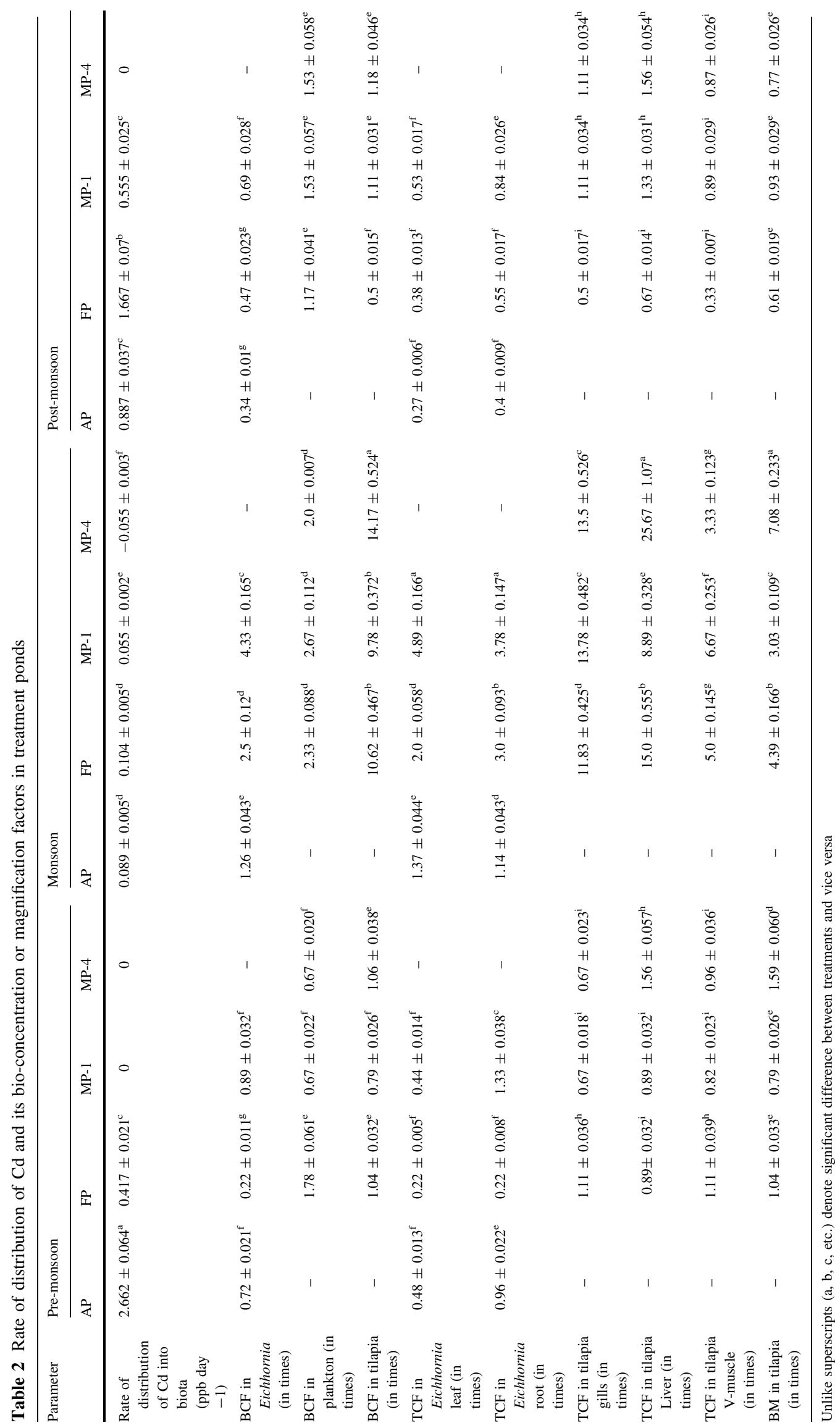




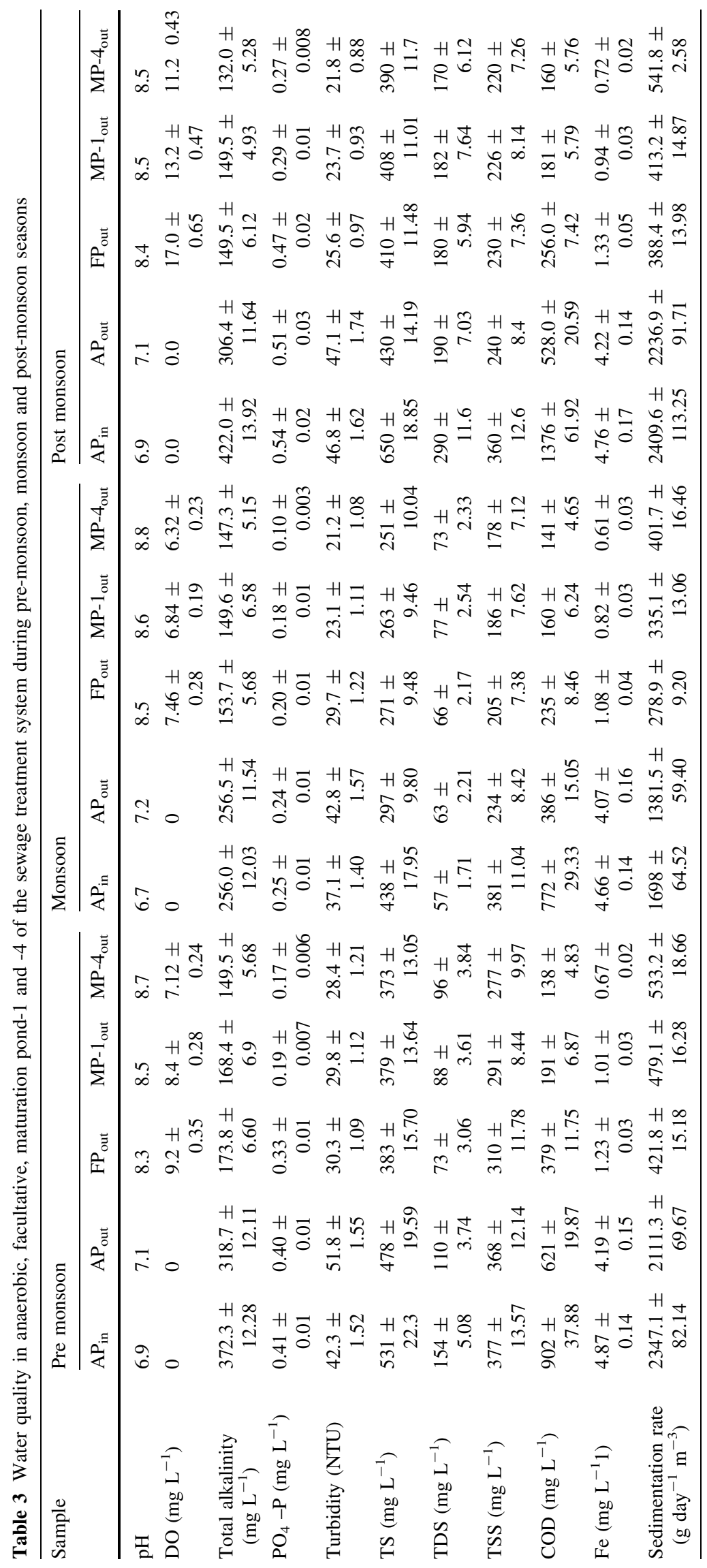


pond-1. For tilapia, the highest tissue concentration factor in gills and V-muscle were observed in facultative pond (Table 2), but the liver showed the highest level in maturation pond-4 (Table 2). Bio-magnification of cadmium in tilapia indicated the highest value was shown in maturation pond- 4 followed by facultative pond (Table 2).

\section{Monsoon}

Cadmium accumulation in sludge decreased gradually from anaerobic pond to maturation pond-1 (61.4-10.65\%) but in maturation pond- 4 , it was slightly increased $(\approx 4 \%)$ (Fig. 2). Rate of metal transfer was highest in facultative pond followed by anaerobic pond, but in maturation pond4, a reverse phenomenon (i.e., depuration) was observed (Table 2). Cadmium accumulation in tilapia showed sequential decrease along the effluent gradient showing following the order of variations: maturation pond-4 $(77.98 \%)>$ facultative pond $(60.8 \%)>$ maturation pond $-1(52.07 \%)$ (Fig. 2). Accumulation in plankton increased gradually from facultative pond to maturation pond-1, but it decreased in maturation pond-4. Tissue concentration factor in Eichhornia leaf and root, increased gradually from anaerobic pond to maturation pond-1. For gills, the factor although augmented from facultative pond into maturation pond- 1 by $16 \%$ notwithstanding, the factor value did not declined significantly (one-way ANOVA; Tukey's test, $P>0.05$; Table 2). In liver, the factor raised from facultative to maturation pond- 4 with a fall of $40.7 \%$ in maturation pond-1 (Table 2). In V-muscle, the factor elevated to $33.4 \%$ in maturation pond-1 but in turn, it declined significantly (50\%; one-way ANOVA; Tukey's test, $P<0.05$; Table 2) to in maturation pond-4. Tilapia was shown the highest bio-magnification in maturation pond-4 (Table 2).

\section{Post-monsoon}

In all ponds, cadmium accumulation was highest in water (29.17-73.10\%; Fig. 2). The accumulations in plankton and tilapia increased gradually from facultative pond to maturation pond-4. The ratio of cadmium accumulation in between water and sludge gradually decreased along the decreasing effluent gradient in the following order: 6:1 (AP) $>5: 1$ (FP) > 3.5: 1 (MP-1 and MP-4) (Fig 2). The rate of transfer gradually declined from facultative pond to maturation pond-4 (Table 2). Tissue concentration factor in Eichhornia leaf and root raised gradually from anaerobic pond to maturation pond-4 (Table 2). Tissue concentration factor in gills, liver and V-muscle followed the trend similar to monsoon (Table 2). Bio-magnification in tilapia was highest in maturation pond-1 followed by maturation pond- 4 and facultative pond (Table 2).
Water quality

$\mathrm{pH}$ decreased gradually from anaerobic pond (6.9-7.2) to maturation pond-4 (8.3-8.8) in all seasons (Table 3). These values in FP, MP-1 and MP-4 were slightly higher during monsoon. During post-monsoon period, the level of dissolved oxygen in FP, MP-1 and MP-4 were above the saturated level (saturation level $8 \mathrm{mg} \mathrm{L}^{-1}$, at $200{ }^{\circ} \mathrm{C}$ APHA 1995). Alkalinity was higher (>300 $\mathrm{mg} \mathrm{L}^{-1}$, Parker 2002) in anaerobic pond in both pre- and post- monsoon (Table 3). COD values also decreased gradually from AP to MP-4 during all seasons (Table 3). COD values in AP was always high (386-1,376 $\mathrm{mg} \mathrm{L}^{-1}$; Table 3) and during pre- and post-monsoon it was very high. In all seasons, the concentration of $\mathrm{Fe}$ was high in AP but in FP this concentration was reduced to $60.71-73.46 \%$ (Table 3).

\section{Cd remediation}

The concentrations of $\mathrm{Cd}$ in water and sludge were reduced by $0-61.11 \%$ in different treatment pond series during in three different seasons (Table 4). The highest remediation efficiency attained its peak in water $(61.11 \%)$ during postmonsoon, but in sludge ( $42.85 \%$ ) during pre-monsoon period (Table 4). Cd reclamation efficiency sustained in sludge beyond $33 \%$ in all the seasons (Table 4), whereas monsoon period was not found favourable for reclamation in water (0\%) (Table 4). The facultative pond (FP) and anaerobic pond (AP) performed better metal reclamation potential during post-monsoon and pre-monsoon, respectively (Table 4).

The topological distribution of cadmium among different components of waste stabilization ponds showed that the metal concentration was reduced gradually along the sewage effluent gradient from anaerobic pond to final maturation pond via facultative pond (Fig. 3). The differential transport and metabolism of metal among different ecosystem components might be the combined effect of physicochemical and biological processes like chelation, sedimentation, adsorption, precipitation, microbial transformation and vertical leaching the soil profile (Fig. 3). In raw sewage, most of the cadmium remained dissolved as ions because of its slight acidic nature $(\mathrm{pH}$ 6.7-6.9; Table 3). When water entered into anaerobic pond, dissolved $\mathrm{Cd}^{2+}$ might begin to precipitate as $\mathrm{CdS}$ and or $\mathrm{Cd}$ $(\mathrm{OH})_{2}$ chelate or adsorbent though the $\mathrm{pH}$ of the water ranged from slightly acidic to slightly alkaline (pH 6.7-7.2). Anoxic condition in AP water (DO $0 \mathrm{mg} \mathrm{L}^{-1}$; Table 3) favoured the formation of $\mathrm{CdS}$ and $\mathrm{Cd}(\mathrm{OH})_{2}$. Very high organic load in AP water also facilitated the chelation process. Formation of $\mathrm{Fe}(\mathrm{OH})_{3}$ coagulum at the surface of AP water adsorbed some $\mathrm{Cd}^{2+}$ from surface AP water. Consequently, cadmium was precipitated along with the sedimentation of organic matter. High sedimentation rate of 
Table 4 Average Cd remediation efficiency of sewage treatment ponds during pre-monsoon, monsoon and post-monsoon periods

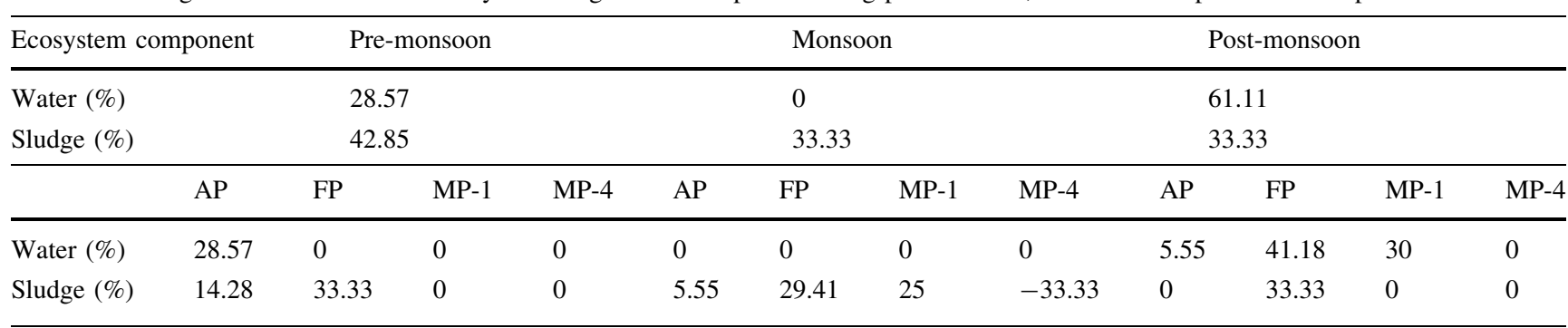

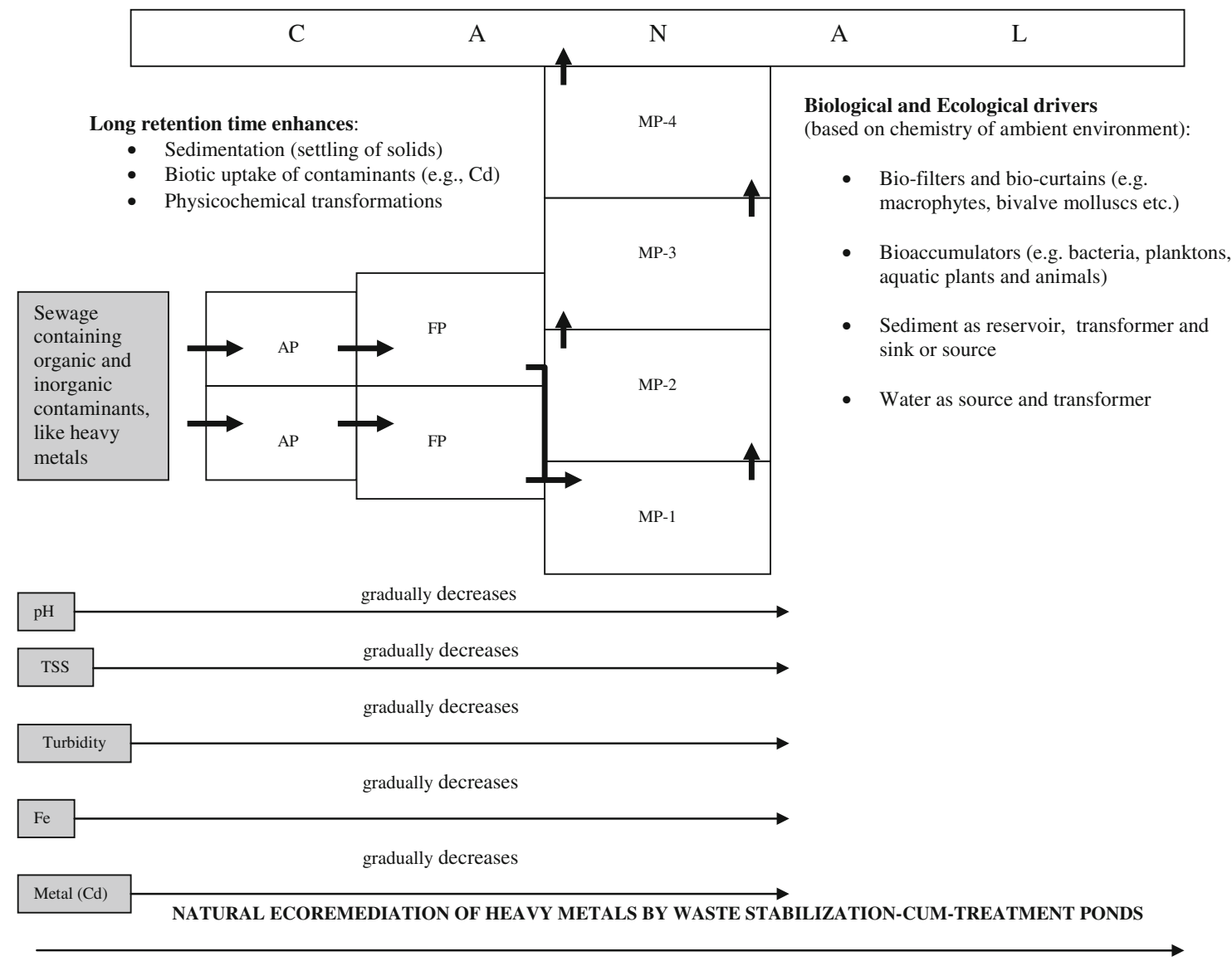

(Combined effect of physicochemical \& biological processes: chelation, sedimentation, adsorption, precipitation, absorption, microbial transformation \& leaching)

Fig. 3 Ecological sewage treatment pond series endowed with metal accumulation, filtration and transformation capacities offer multiple ecosystem services of wastewater reclamation, resource recovery and heavy metal remediation

organic matter in AP $\left(1381.5-2,409.6 \mathrm{~g} \mathrm{day}^{-1} \mathrm{~m}^{-3}\right.$; Table 3) implied that $\mathrm{Cd}$ was precipitated rapidly in AP and this was true during pre-monsoon, monsoon and post-monsoon periods. Presence of profuse oxygen molecules (DO 7.46-17.0 $\mathrm{mg} \mathrm{L}^{-1}$; Table 3) in facultative pond created the conducive environment for the formation of $\mathrm{Fe}(\mathrm{OH})_{3}$ and its subsequent removal from FP water were observed to be highest during all three seasons. Thus, adsorption of $\mathrm{Cd}^{2+}$ by $\mathrm{Fe}$ coagulum and its precipitation happened to be a significant phenomenon in FP. High organic load and Fe content in water (TS 297-531 $\mathrm{mg} \mathrm{L}^{-1}$; COD 386-902 $\mathrm{mg} \mathrm{L}^{-1}$;
Fe 4.07-4.87 $\mathrm{mg} \mathrm{L}^{-1}$; Table 3) and its higher sedimentation rate in anaerobic pond $\left(1381.5-2,347.1 \mathrm{~g} \mathrm{day}^{-1} \mathrm{~m}^{-3}\right.$; Table 3) caused higher rate of accumulation of cadmium in sediment than in water during pre-monsoon and monsoon seasons. But during post-monsoon period, this trend reversed significantly for facultative, maturation pond- 1 and maturation pond -4 . This might be due to lower aquatic temperature during post-monsoon period that had inhibited associated adsorption and chelation processes. During monsoon, no Cd was detected in water implying its presence below the detectable limit of the AAS. During pre-monsoon, 
comparatively lower organic load and Fe content coupled with lower sedimentation rate of facultative, maturation-1 and -4 ponds (Table 3 ), resulted in augmented accumulation of cadmium in water compared to sludge. Dilution effect during monsoon resulted in slower rate of interfacial transfer and distribution of $\mathrm{Cd}$ among different biotic components in all the ponds compared to pre- and post-monsoon periods. The relatively higher and lower concentration during premonsoon and monsoon season, respectively, may be justified by evaporation and dilution effects related to respective reasons. Precipitation can enhance infiltration of metals by altering soil structure and porosity. In monsoon, the rate of distribution of cadmium in maturation pond- 4 became negative ( $-0.055 \mathrm{ppb} \mathrm{day}^{-1 \text {; }}$ Table 2$)$. This might be due to very lower concentration of cadmium in abiotic ambience (average $0.6 \mathrm{ppb}$, Table 1) than the concentration within biotic components (average $6.68 \mathrm{ppb}$; Table 1). However, certain amount of cadmium was excluded competitively by water molecules from the body of plankton and tilapia. Bioaccumulation is the function of difference in concentration between living interior environment and ambience. Eichhornia behaved as an excellent absorbent of heavy metal owing to its immense inherent biofilter potential and its absorption depended on the ionic concentration of cadmium in water. Marentes and Rauser (2007) reported that metallothianein protein found in root of Eichhornia entrapped cadmium to a great extent. So, during all three seasons, higher ambient cadmium concentration became greater rate of accumulation of cadmium by Eichhornia as noticed in AP in comparison to FP and MP-1 (Fig. 2) suggesting cadmium accumulation as concentration gradient dependent process all along the sewage effluent gradient. In case of plankton community, the accumulation was high in facultative, maturation- 1 and maturation- 4 ponds in premonsoon, monsoon and post monsoon (11.01-35.3\%; Fig. 2) because of complex multitude of interaction of cadmium within different components of pond system; namely, absorption of water, adsorption of cadmium with body wall, consumption of bacteria and consumption of sludge. Depending on the higher concentration of the ambient cadmium got accumulated within the body of tilapia through food chain. Tilapia consumed sludge, Eichhornia root and plankton. Certain $\mathrm{Cd}^{2+} \mathrm{s}$ diffused inside through the epithelial lining of gills. Within the prevailing $\mathrm{pH}$ range of facultative, maturation-1 and maturation-4 ponds water ( $\mathrm{pH}$ 8.4-8.8; Table 3 ) certain cadmium could remain as ion that goes in conformity with the observation of Zhang et al. (2003) that heavy metals remained ionized to some degree at elevated $\mathrm{pH}$ level (8.15-12.87) in his study. Therefore, the accumulation within the body of tilapia was measured high (12.1-77.98 \%; Fig. 2) all the seasons in FP, MP-1 and MP-4. The accumulation reached the highest level (52.07-77.98\%, Fig. 2) among all which was observed to be highest growth rate of tilapia during monsoon and associated highest consumption of metal rich sludge sludge, plankton and Eichhornia root. and such accumulation was highest $(77.98 \%)$ in maturation pond-4 due to prevailing ambient physicochemical attributes of water which were conducive to fish growth. The physicochemical profile ( $\mathrm{pH}, \mathrm{DO}$, total alkalinity, $\mathrm{PO}_{4}-\mathrm{P}$, turbidity, TS, TDS, TSS and COD) in the maturation pond and Fe stress-free condition created congenial conditions for fish culture. Moreover, very low concentration of $\mathrm{Fe}$ in maturation pond4 water $\left(0.72 \mathrm{mg} \mathrm{L}^{-1}\right)$ might have facilitated absorption of cadmium from water as well as from stomach. Bio-magnification was conditioned by the degree of bio-concentration of the heavy metal. Bio-accumulation again was the function of frequency and extent of feeding of tilapia on sludge, detritus, Eichhornia root and planktons as well as of the aquatic breathing through gills. Naturally, highest bioconcentration in tilapia during monsoon reflected the co-dependent bio-magnification of similar magnitude.

Cadmium remediation from water and sludge of eight sewage treatment ponds during pre-monsoon, monsoon and post-monsoon was resulted from diverse physico-chemical and biological processes, viz. chelation, adsorption and sedimentation, absorption and bio-accumulation, ionization and leaching through sediment. No reclamation was witnessed in monsoon due to dilution effect of ample rainfall. Higher concentration of total solids (390-650 $\mathrm{mg} \mathrm{L}^{-1}$; Table 3), accompanied sedimentation rate (388.4-2,409.6 $\mathrm{g} \mathrm{day}^{-1} \mathrm{~m}^{-3}$; Table 3$)$ in association with elevated Fe concentration in water $\left(0.72-4.76 \mathrm{mg} \mathrm{L}^{-1}\right.$; Table 3) (resulting in $\mathrm{Fe}(\mathrm{OH})_{3}$ coagulum) culminated into optimum Cd reclamation from water in post-monsoon period.

\section{Conclusion}

In sewage treatment ponds, cadmium was partitioned among different biotic and abiotic ecosystem components.

Bio-accumulation within Eichhornia gradually decreased from anaerobic pond to maturation pond-4 down the effluent concentration gradient in all seasons in contrast to tilapia wherein it increased gradually, reaching the peak during monsoon. Hepatic accumulation exceeded branchial and muscular accumulation in all seasons.

The accumulation within gills, liver and $\mathrm{V}$-muscle remained within the safe level $\left(1 \mu \mathrm{g} \mathrm{kg}^{-1}\right.$; WHO 2008) and might not have any possibility of posing threat from human health perspective. Therefore, it may be recommended for human consumption. The sewage treatment ponds are efficient in reclamation of cadmium from water and sludge in all seasons and the reclamation efficiency of facultative pond in post monsoon and anaerobic pond in pre-monsoon are better. 
The sewage treatment ponds may be promoted as a lowcost sustainable eco-tech for heavy metal as well as water quality remediation. The reclaimed water can be used for agricultural irrigation purposes.

Acknowledgments This study was financed by University of Kalyani to S. Rana as fellowship.

\section{References}

APHA (American Public Health Association). AWWA (American Water Works Association). WEF (Water Environment Federation) (1995). Standard Methods for the Examination of Water and Wastewater. 19th edn. American Public Health Association, Washington, DC, pp 1-911

Baccini P (1984) Regulation of trace metal concentration in fresh water systems. In: Segal H (ed) Metal ions in biological systems. Circulation of metals in the environment, vol 18. Marcel Dekker, New York

Biswas JK, Santra SC (2000). Heavy metal levels in marketable vegetables and fishes in Calcutta Metropolitan Area, India. In: Jana BB, Baneerjee RD, Guterstam B, Heeb J (eds) Waste Recycling and Resource Management in the Developing WorldEcological Engineering Approach. University of Kalyani, India and International Ecological Engineering Society, Switzerland

Buffle J (1984) Natural organic matter and metal-organic interactions in aquatic systems. In: Segal H (ed) Metal ions in biological systems. Circulations of metals in the environment, vol 18. Marcel Dekker, New York

Canterford GS, Canterford DR (1980). Toxicity of heavy metals to the marine diatoms Ditylum brighatwellu (West) Gruno W. Correlation between toxicity and metal speciation. J mar biol Ass UK 60: 227-242

Casalino E, Calzaretti G, Sblano C, Landriscina C (2002) Molecular inhibitory mechanisms of antioxidant enzymes in rat liver and kidney by cadmium. Toxicology 179(1-2):37-50

Croteau Marie-Noele Luoma SN, Stewart AR (2005) Trophic transfer of metals along freshwater food webs: evidence of cadmium biomagnification in nature. Limnol Ocenogr 50(5):1511-1519

Das S, Jana BB (2004) Distribution pattern of ambient cadmium in wetland ponds along an industrial complex. Chemosphere 55(2): $175-185$

De AK (2000) Environmental chemistry, 4th edn. New Age International Publishers, New Delhi

Fredickson JK, Kostandarithis HM, Li SW, Plymale AE, Daly MJ (2000) Reduction of Fe(iii) $\mathrm{Cr}$ (iv), U(vi) and Tc(vii) by Deinococcus radiodurans R1. Appl Environ Microbiol 66:2006-2011

Greter FL, Buffle J, Aherdi W (1979) Voltammetric study of humic and fulvic substances -1: study of the factors influencing the measurement of their complexing properties with lead. J Electroanal Chem 101:211-229

Haq AHMR, Ghosal TK (2000). Wastewater reclamation using duckweed. In: Jana BB, Baneerjee RD, Guterstam B, Heeb J (eds) Waste Recycling and Resource Management in the Developing World-Ecological Engineering Approach. University of Kalyani, India and International Ecological Engineering Society, Switzerland

Hollis L, Hogstrand C, Wood CM (2001) Tissue-specific cadmium accumulation, metallothionein induction, and tissue zinc and copper levels during chronic sublethal cadmium exposure in juvenile rainbow trout. Arch Environ Contam Toxicol 41(4): 468-474

Igwe JC, Abia AA (2006) Review: a bioseparation process for removing heavy metals from waste water using biosorbents. Afri J Biotechnol 5(12):1167-1179
Jalali M, Khanboluki G (2007) Leaching of zinc. Cadmium and lead in a sandy soil due to application of poultry litter. Soil Sed Contam 16:47-60

Kaoud Hussein A, Moustafa Zaki Manal, El-Dahshan Ahmed R, Sherein Saeid, El Zorba Y (2011) Amelioration the toxic effects of cadmium-exposure in Nile Tilapia (Oreochromis Niloticus) by using Lemna gibba L. Life Sci J 8(1):185-195

Kaplan D, Abeliovich A, Ben-Yaakov S (1987) The fate of heavy metals in wastewater stabilization ponds. Wat Res 21(10):1189-1194

Kerrison PH, Annoni D, Zarini S, Ravera O, Moss B (1988) Effect of low concentration of heavy metals on plankton community dynamics in a small, shallow, fertile lake. J Plankton Res 10(4):779-812

Landis WG, Yu M-H (1999). Introduction to environmental toxicology: impacts of chemicals upon ecological systems. 2nd edn. CRC Press, Lewis Publishers, USA

Lane TW, Morel FMM (2000) A biological function for cadmium in marine diatoms. Proc Natl Acad Sci USA 97(9):4627-4631

Lazareva O, Pichler T (2010) Long-term performance of a constructed wetland/filter basin system treating wastewater. Central Florida. Chem Geol 269:137-152

Liu J, Dong Y, Xu H, Wang D, Xu J (2007) Accumulation of Cd, Pb and $\mathrm{Zn}$ by 19 wetland plant species in constructed wetland. J Hazard Mater 147:947-953

Lucas JS, Southgate PC (2003). Aquaculture: Farming aquatic animals and plants. Blackwell Publishing, USA

Maine MA, Sune N, Hadad H, Sánchez G, Bonetto C (2007) Removal efficiency of a constructed wetland for wastewater treatment according to vegetation dominance. Chemosphere 68:1105-1113

Marentes E, Rauser WE (2007) Different proportions of cadmium occurs as $\mathrm{Cd}$ binding phytochelatin complexes in plant. Physiol Plant 131(2):291-301

Novelli ELB, Vieira EP, Rodrigues NL, Ribas BO (1998) Risk assessment of cadmium toxicity on hepatic and renal tissues of rats. Environ Res Sect A 79(2):102-105

Parker R (2002) Aquaculture Science, 2nd edn. Delmar Thomson Learning, Albany, NY

Piotrowicz SR, Harvey GR, Spring-Young M (1983). Studies of cadmium. Copper and zinc interactions with marine fulvic and humic materials in sea water using stripping voltammetry. In: Wong et al. (eds) Trace Metals in Sea Water. Plenum, New York

Singh D, Tiwari A, Gupta R (2012) Phytoremediation of lead from wastewater using aquatic plants. J Agric Technol 8(1):1-11

Stoveland S, Lester JN, Perry R (1979) The influence of nitrilotriacetic acid on heavy metals transfer in activated sludge process-I at constant loading. Wat Res 13:949-965

Vaglio A, Landriscina C (1999) Changes in liver enzyme activity in the teleost Sparus aurata in response to cadmium intoxication. Ecotoxicol Environ Saf 43(1):111-116

Van Campenhout K, Infante HG, Adams F, Blust R (2004) Induction and binding of $\mathrm{Cd}, \mathrm{Cu}$ and $\mathrm{Zn}$ to metallothionein in carp (Cyprinus carpio) using HPLC-ICP-TOFMS. Toxicol Sci 80(2):276-287

Vymazal J (2007) Removal of nutrients in various types of constructed wetlands. Sci Tot Environ 380(1-3):48-65

Vymazal J (2010) Constructed wetlands for wastewater treatment. Water 2(3):530-549

World Health Organization (WHO) (2006) Guidelines for the safe use of wastewater. excreta and greywater. wastewater and excreta use in aquaculture. World Health Organization, vol 3, Geneva. Switzerland

World Health Organization (WHO) (2008) Guidelines for drinkingwater quality, vol 1, 3rd edn. World Health Organization, Geneva

Zhang G, Cong-Q Liu, Yang Y, Wu P (2003) Characterization of heavy metals and sulphur isotope in water and sediments of a mine tailing area rich in carbonate. Water Air Soil Pollut 155(1-4):51-62 